\title{
CARS AND KARST: INVESTIGATING THE NATIONAL CORVETTE MUSEUM SINKHOLE
}

\author{
Jason S. Polk
}

Western Kentucky University, 1906 College Heights Blvd., Bowling Green, KY, 42101, USA, jason.polk@wku.edu

\section{Leslie A. North}

Western Kentucky University, 1906 College Heights Blvd., Bowling Green, KY, 42101, USA, leslie.north@wku.edu

\section{Ric Federico}

EnSafe, Inc., 1148 College Street, Bowling Green, KY, 42101, USA rfederico@ensafe.com

\section{Brian Ham}

EnSafe, Inc., 220 Athens Way, Ste 410, Nashville,TN, 37228,USA, bham@ensafe.com

\section{Dan Nedvidek}

EnSafe, Inc., 1148 College Street, Bowling Green, KY, 42101, USA, dnedvidek@ensafe.com

\section{Kegan McClanahan}

Western Kentucky University, 1906 College Heights Blvd., Bowling Green, KY, 42101, USA,

kegan.mcclanahan@wku.edu

\section{Pat Kambesis}

Western Kentucky University, 1906 College Heights Blvd., Bowling Green, KY, 42101, USA, pat.kambesis@wku.edu

\section{Michael J Marasa}

Hayward Baker, Inc., 53 Century Blvd., Suite 200, Nashville,TN, 37214, USA, MJMarasa@HaywardBaker.com

\begin{abstract}
On February 12th, 2014, a sinkhole occurred at the National Corvette Museum in Bowling Green, Kentucky. The collapse happened inside part of the building known as the Skydome and eight Corvettes on display were lost into the void that opened in the concrete floor. In this region of Kentucky, known as the Pennyroyal sinkhole plain, subsidence and cover collapse sinkholes are commonly found throughout the landscape. This iconic karst region in the United States is also home to Mammoth Cave, the longest cave in the world, and thousands of other caves and karst features. Investigation of the sinkhole collapse began immediately while the Corvettes were extracted from the debris cone inside the void. Techniques used for investigation included water jet drilling, downhole cameras and drone footage, a microgravity surface survey, and mapping of the void and accompanying cave. After exploration of the sinkhole by karst researchers and compilation of the data, the cause of the sinkhole was determined to be a cave roof collapse in a breakout dome. The cave underlying the col-
\end{abstract}

lapse is about $220 \mathrm{ft}$. $(67 \mathrm{~m})$ long and $39 \mathrm{ft} .(12 \mathrm{~m})$ wide on average with an average depth of 65-85 ft. (20-25 m). The structural integrity of the bedrock (thinly interbedded limestone and chert located at a contact between two major limestone units) is lacking in the area. Talus and breakdown are abundant in the cave in which the sinkhole formed. The progression of the roof failure likely occurred over a long span of time, eventually giving way due to a variety of conditions, including speleogenetic and climatic factors. Current remediation is underway and involves filling the sinkhole with gravel and sand, then installing a micropile supported concrete slab floor under the building. Future changes to the structure will be monitored to detect any activity.

\section{Introduction}

On February 12th, 2014, a sinkhole occurred at the National Corvette Museum in Bowling Green, Warren County, Kentucky. The collapse happened inside part of the building known as the Skydome, which is a large circular structure connected to the main building where rare Corvettes are displayed (Figure 1). On the day of 


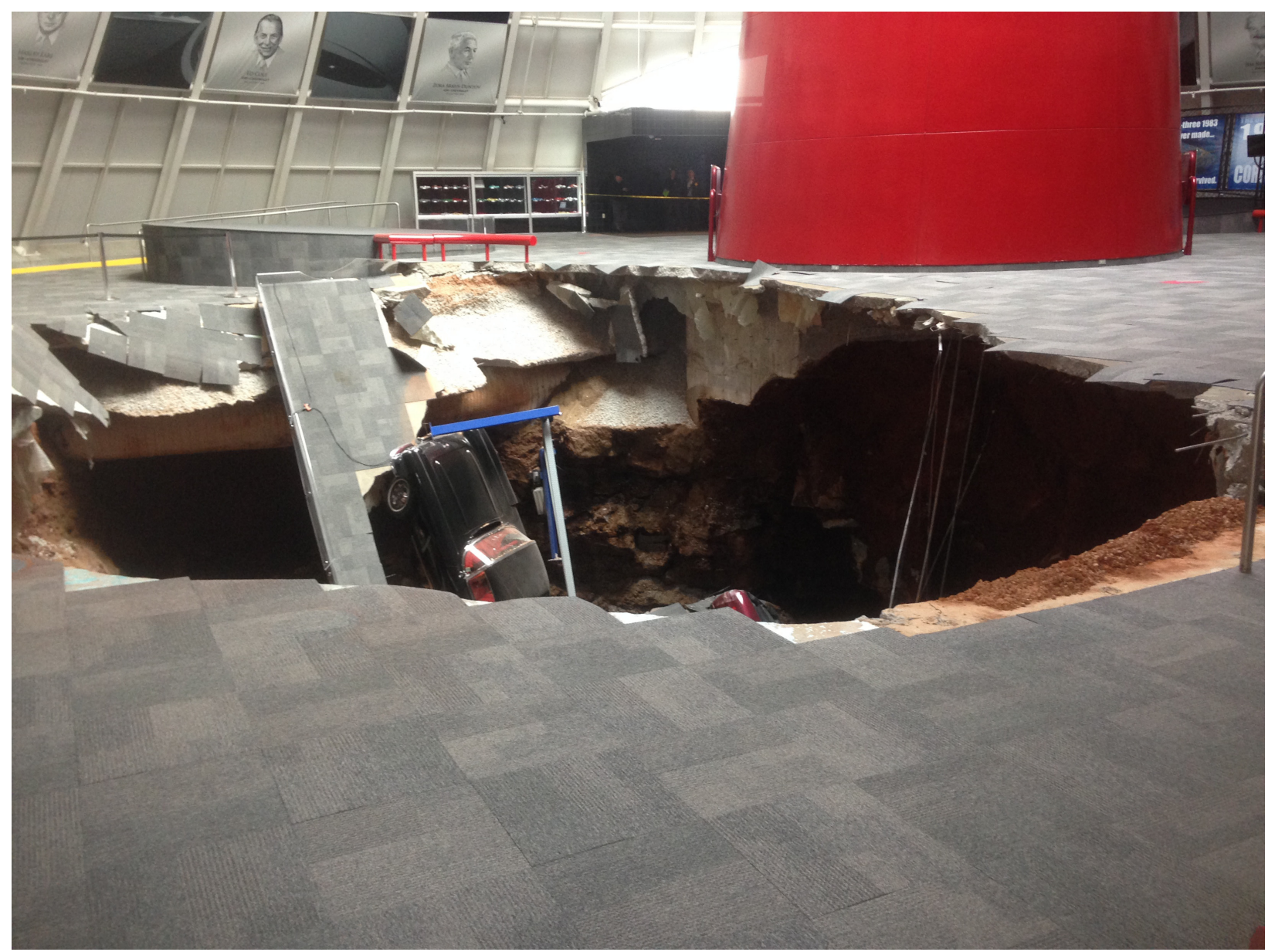

Figure 1. Initial sinkhole collapse: The original collapse on the day it occurred at the National Corvette Museum in Bowling Green, Kentucky.

the collapse, eight Corvettes on display were lost into the void that opened in the concrete floor.

In this region of Kentucky, known as the Pennyroyal sinkhole plain, subsidence and cover collapse sinkholes are commonly found throughout the landscape (Ford and Williams 2007, Palmer 2007, North et al. 2014). This is an iconic karst region in the United States and home to Mammoth Cave, the longest cave in the world, and hundreds of other caves and karst features.

In Bowling Green, sinkhole collapses are not uncommon, with many having been mapped by the Kentucky Geological Survey and others that occur on a regular basis, though usually on a smaller scale and often unreported (KGS 2015). There are also over 200 documented caves in Warren County, Kentucky (KSS 2014), lending merit to the potential for sinkholes and cave collapses given the highly karstified nature of the bedrock. Despite this potential, sinkholes do not usually pose a high threat to the community.

\section{Sinkhole Types}

In many classic karst settings, most sinkhole collapses form from regolith arch failure, where cohesive soils, usually dense clays, create an arch that eventually gives way from below due to undermining caused by spalling of materials into voids during water movement (i.e. storm events large enough to cause infiltration). These types of sinkhole often form rapidly and can cause immediate threat to life and property if they occur in developed areas. Other common sinkholes in south-central Kentucky occur as subsidence landforms, or closed depressions, where surface soils slowly spall into cavities below over long periods of time. These features create a gentle depression in the landscape that sometimes has a "throat" in the center, but usually pose little risk to life or property. A third type of sinkhole, though less common, results from cave roof collapse. Though not as well documented, these types of sinkhole collapses are found throughout the study area, including past examples like the Dishman Lane sinkhole (Kambesis et al. 2003) and several collapsed cave entrances, such as 
Lost River Cave's main entrance and Crumps Cave in Smith's Grove, Kentucky (Crawford et al. 1989; Polk et al. 2013). As structural integrity of the overlying bedrock weakens through geologic time, the cave roof forms a breakout dome, or cantilevered dome, which eventually fails in a similar manner as a cohesive soil arch, with a sudden, catastrophic collapse of the roof and overlying materials into the cave below (Loucks 2007). These types of sinkholes are hard to detect and predict, but examples can be found throughout the world of both small and large feature of this type.

\section{Study Area}

The National Corvette Museum is located in the Pennyroyal Plateau, which encompasses the Pennyroyal sinkhole plain of south-central Kentucky. The Skydome structure sits atop the contact between the Ste. Genevieve and St. Louis limestones (Figure 2), both of which are Mississippian aged formations that comprise a large majority of the cave-forming bedrock in the region, including hosting many of Mammoth Cave's passages (Palmer 1981, Palmer 2007). These formations are often thinly bedded at the contact and dip gently toward the north. The Corydon ball chert layer is present and located at the contact between the Ste. Genevieve and St. Louis limestones. Sinkholes, both shallow and deep, are prominent features throughout the landscape and vary in depth based on the rock unit in which they form (Howard 1968). Adjacent to the Skydome to its south and northwest are large subsidence sinkholes. The southern sinkhole holds water throughout the year due to compacted clays or an impermeable chert layer at its bottom, or a combination of both.

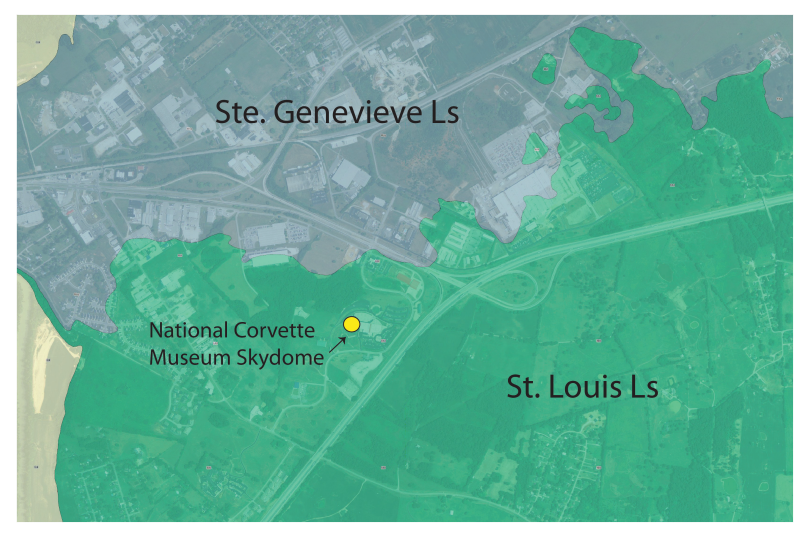

Figure 2. Local Geology at the Skydome: The Skydome is located near the contact between the Ste. Genevieve and St. Lovis limestones on the Pennyroyal sinkhole plain. Data from the KGS Map Information Service.
The epikarst zone is easily identified due to the highly weathered limestone bedrock at the soil-rock interface, which provides a discontinuous boundary of pinnacleand cutter-type limestone features. Soil cover consists of thin, heterogeneously distributed Baxter and Crider soils. Baxter soils are often found on hillslopes and are deep, well-drained soils consisting of fine-textured gravelly-silt loam, sometimes overlying the Crider red silt loams and clay loams covering the region (Soil Survey Staff 2015).

Surface water flow is absent in much of the area due to the highly karstified landscape. Water is rapidly internally drained to the subsurface through various conduits until reaching the water table below. The regional aquifer level is often located up to 160 to $200 \mathrm{ft}$. (48 to 62 $\mathrm{m})$ below the surface. Precipitation averages 51 inches $(1,300 \mathrm{~mm})$ per year and the climate is humid-subtropical, though the average annual temperature is near $55^{\circ} \mathrm{F}$ $\left(13^{\circ} \mathrm{C}\right)$.

\section{Investigation Methods}

The sinkhole investigation began immediately after the collapse using a drone fitted with a camera to determine if there were additional voids or passages beneath the sinkhole, but the data were inconclusive. Micropile drilling to support the Skydome structure and the "spire" in its center, which provides structural support commenced and provided an opportunity for additional investigation. Downhole cameras were used in the holes drilled for the micropiles in an attempt to identify any additional cavities or passages extending from the main sinkhole collapse. Data recorded during water jet drilling of the micropiles allowed for generalized fence mapping of the drill logs, which provided basic information on depth to competent bedrock and additional voids surrounding the main collapse. Subsequently, a microgravity survey on a 10-foot grid (3-m) was conducted in the area surrounding the sinkhole and a buffer area outside the Skydome. Compilation of these data indicated the need for further exploration due to the possibility of additional voids extending from the main sinkhole opening away from the debris cone.

Prior to exploration and mapping, construction company Scott, Murphy \& Daniel, LLC worked with karst scientists from Western Kentucky University (WKU) to develop a plan for removing the eight Corvettes and stabilize the sidewalls of the sinkhole, which had weakened and fractured concrete slabs cantilevered beyond the edge of the hole and over loose sediments. Construction workers were trained on vertical caving techniques and the Corvettes were removed using a combination of techniques to strap them to 36 -ton $(36,000 \mathrm{~kg})$ crane 
booms and lift them from the sinkhole. All eight were recovered with varying amounts of damage, with some completely destroyed from the large breakdown that fell into the hole on top of them (Figure 3).

After retrieval of the Corvettes and stabilization of the hole, a team from WKU and EnSafe explored the sinkhole and discovered additional cave passages (Figure 4). A grade 5 cave survey was undertaken to map the sinkhole and cave passages. This was tied in to the surface engineering survey in order to better determine possible areas of concern and to develop a remediation plan for repairing the Skydome floor and any other structures outside the building as needed.

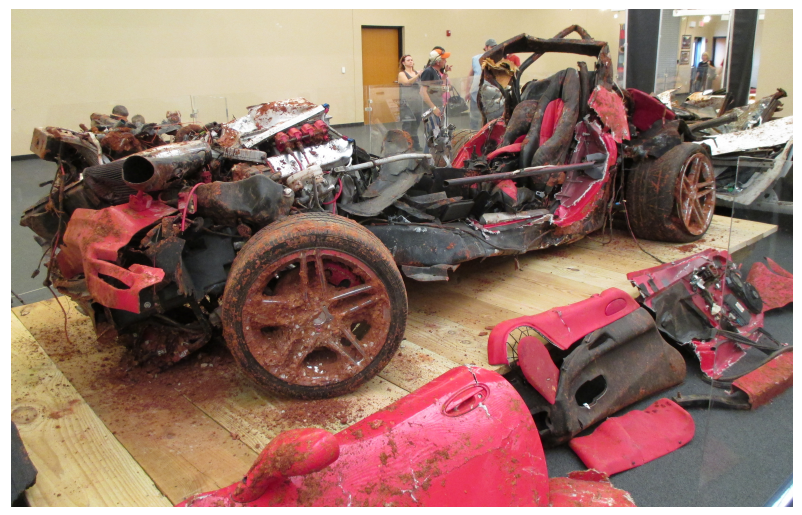

Figure 3. Remains of a Corvette: After extraction from the sinkhole, some Corvettes were repaired, while others were damaged beyond repair. Three were fixed by General Motors and private funds, and the others are on display at the Museum.

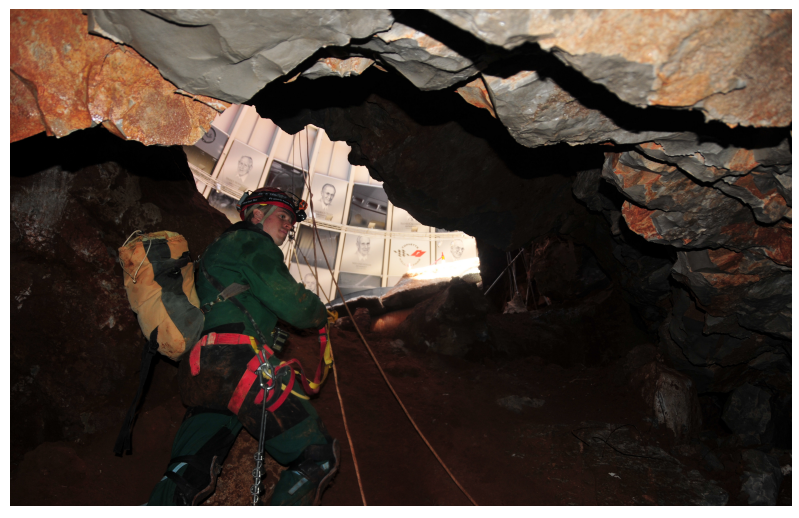

Figure 4. Entrance to southern cave passage: Brian Ham of EnSafe, Inc. stands at the entrance of the southern cave passage. The cantilevered breakout dome can be seen as the sinkhole walls migrate upward.

\section{Discussion}

The oval-shaped opening to the sinkhole measured approximately $36 \mathrm{ft}$. (11 m) at its longest axis, which is oriented just east of due north. Microgravity and drill log investigations, combined with visual clues, revealed the possibility of additional cave passage extending from the sinkhole to the north and south. Exploration and survey of the sinkhole concluded that it was a collapsed portion of a cave roof that failed and formed the sinkhole opening. The cave measures $220 \mathrm{ft}$. in length $(67 \mathrm{~m})$ and averages $40 \mathrm{ft} .(12 \mathrm{~m})$ in width. The deepest location is approximately $80 \mathrm{ft}$. $(25 \mathrm{~m})$ below the floor of the Skydome. The passages extend beyond the Skydome structure and trend toward existing sinkholes to the north and south, likely already collapsed portions of the same relic cave system. This verified the data from the microgravity survey, which indicated the potential for voids in these areas.

Inside the cave, the debris cone consists mainly of large breakdown and weathered limestone, with some overlying soils. The limestone comprising the cave walls was thinly bedded. The sinkhole is located at the contact between the St. Louis and Ste. Genevieve, where the Corydon ball chert layer (present in the ceiling, Figures 5 and 6) created conditions for instability over the span of the breakdown dome that failed. As the layers of rock collapsed over time, the breakdown dome continued to migrate upward toward the floor of the Skydome and likely was already fairly thin prior to its construction, as this would have been a slow geologic process. Additional wedging from calcite mineral formation between

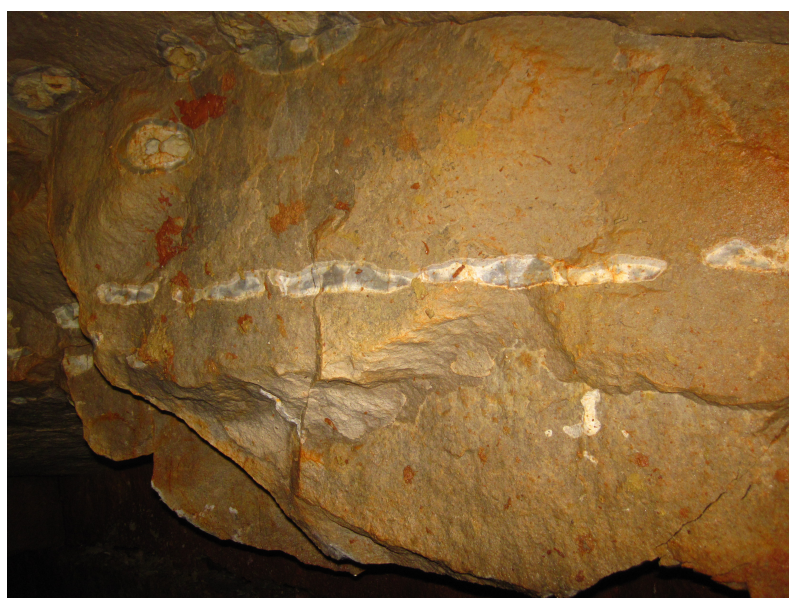

Figure 5. Chert layer: Remnants of a layer of Corydon ball chert, which appears to be cleaved off from where the surrounding limestone has broken away, revealing the impurities that amplified the rock's weakness. 


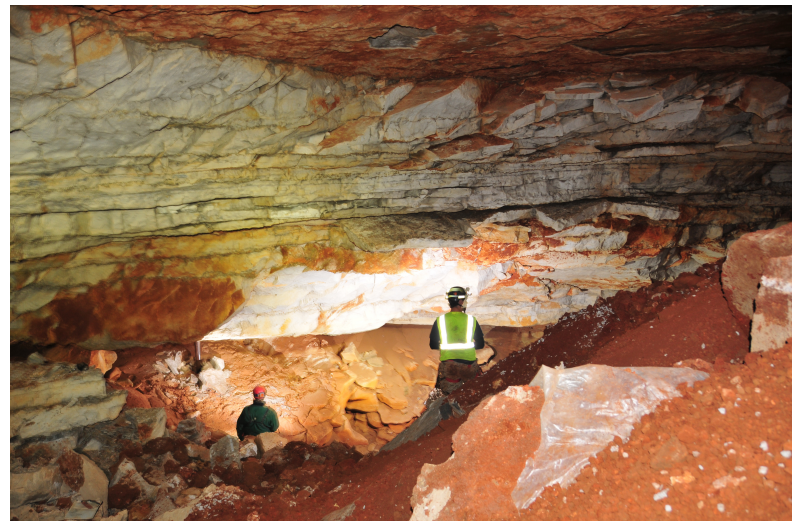

Figure 6. Thinly bedded limestone: The walls of the cave passage in the northern section of cave leading up to the sinkhole entrance. Thinly bedded St. Louis limestone layers are clearly visible.

the limestone beds likely created further weakness in the structure of the rock. There are many stylolites found within the limestone beds as well, along the planes of which additional points of weakness exist. These lateral stylolitic seams can enhance fluid flow and dissolution along their path, where delamination and cracking can occur (Heap et al. 2013), as was observed in the cave. Over time, a breakout dome formed and migrated upward, thinning the bedrock support and creating a situation wherein structural failure and the sinkhole collapse was imminent.

Hayward-Baker, Inc. (Nashville, Tennessee) was consulted and a plan was formulated to repair the sinkhole and Skydome using micropiles to support a concrete slab floor (Figure 7). The debris cone was first smoothed flat and a one-foot $(0.3 \mathrm{~m})$ thick concrete slab was poured, then a double layer of metal sheet pilings were laid horizontally over it and cut to fit the shape of the sinkhole walls. The sinkhole walls were covered in specific areas with shotcrete to stabilize them further. The sheet pilings served as a base for filling the remainder of the hole to the floor with 4000 tons $(3.5 \times 106 \mathrm{~kg})$ of manufactured sand to support the concrete floor. The primary purpose of the sheet pilings is to block the manufactured sand from filling the north and south passages. Its function is to provide support to micropile drilling equipment and temporary support for structural concrete slab construction. Holes were cut in the sheet pilings to drill the micropiles down to the bedrock. The micropiles are 7 inches $(17 \mathrm{~cm}$ ) in diameter (Figure 7) and will be placed at an average depth of $141 \mathrm{ft}$. (43 m), with a range of 130

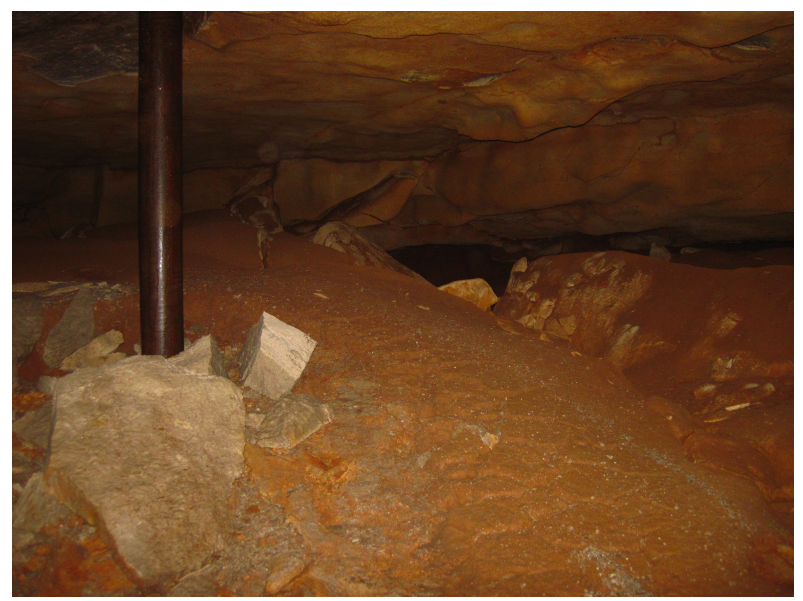

Figure 7. Micropile under the Skydome: A micropile breaching the northern cave passage that was installed to support the Skydome structure before the remediation of the sinkhole was initiated.

to $200 \mathrm{ft}$. (39-55 m) below the floor to reach competent bedrock and will be tied into the concrete slab floor to provide support. The 46 micropiles are installed on a 20 x 25 foot (roughly $6 \mathrm{~m}$ ) grid under the Skydome; there are 23 existing micropiles in place under the footprint of the building and the spire in the center.

Once the construction is complete, the Skydome structure and floor will be independently supported by the micropiles and thus protected from any further collapse or subsidence should either occur in the future. A 4-foot diameter $(1.2 \mathrm{~m})$ manhole was left in the floor to access the southern cave passage for additional scientific monitoring and also to integrate into an exhibit. The Corvette Museum is working on an interactive exhibit to provide visitors an educational experience about the sinkhole's development and repair, as well as information about karst landscapes.

\section{Conclusion}

The sinkhole at the National Corvette Museum on February 12th, 2014 caused damage to the eight rare Corvettes that fell in the hole. Fortunately, the cars were recovered and study of the sinkhole was possible during this process. Investigation of the sinkhole using multiple methods revealed it was part of a larger cave system and aggregated to increase the confidence that the feature is limited to the vicinity of the Skydome. Compilation of the various data, cave map, and observations provided the explanation of the sinkhole resulting from the failure of the cave's roof, which was made up of thinly-bedded and impure limestone. While not as common, these types 